\title{
Dialogic Discourse Analysis: A methodology for dealing with the classroom as a text
}

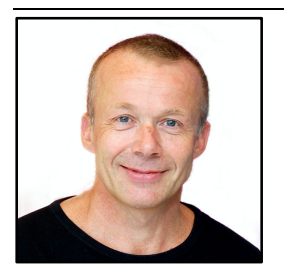

Atle Skaftun

University of Stavanger, Norway

\begin{abstract}
Bakhtin is a source of theoretical inspiration for educational research. This article will be an attempt to activate also Bakhtin's analytical practice and his methodology. I will explore and elaborate the typology of discursive relations which are suggested in Bakhtin's book on Problems of Dostoevsky' Poetics (Bakhtin ,1984), and the potential application of it in the study of discourse in the classroom. In order to do so properly it will be necessary to activate Bakhtin's understanding of the utterance as a meaningful unity, and thus also the problem of authorship and the relationship between author and hero.

Bakhtin's analytical practice can be considered a consistent methodology for the study of literature in schools as well as in the scholarly study of literature (cf. Skaftun, 2009; 2010), and I have called it dialogic discourse analysis (DDA). The first main part of the article elaborates key features of DDA in dialogue with Bakhtin's work. In the other main part, $D D A$ is applied to educational settings in order to enter the educational dialogue on how to make sense of authorship and the adhering conception of the classroom as a text. My ambition here is primarily to elaborate DDA as a powerful and dynamic toolkit also for educational research. In doing so I also hope to contribute to the ongoing work of transferring Bakhtin's dialogism as a whole from the study of literature to the study of education. Examples will in part be drawn from literature, but for the most part from educational settings.
\end{abstract}

Atle Skaftun is a professor in literacy studies at the University of Stavanger. His disciplinary background in Scandinavian Studies with a dissertation on Knut Hamsun's Dialogic Realism (2002). After this his research interests have shifted towards educational contexts. He has written articles and books about literacy and literature education, and lately he has also worked more explicitly with digital and oral conditions for dialogic participation and thinking in Norwegian classrooms.

$\cos 0380$

\section{Introduction}

The Russian philosopher of language and literature, Mikhail Bakhtin, is an important source of inspiration for sociocultural educational research, and particularly for those working within programs or frameworks that are associated with dialogic pedagogy (Alexander, 2008; Mercer, 2000; Matusov, 2009; Mortimer \& Scott, 2003; Nystrand, 1997; Reznitskaya, 2012; Reznitskaya \& Wilkinson, 2017; Wells, 1999). ${ }^{1}$ A lot of Bakhtinian concepts and ideas are established as useful in education without any lengthy explanation transferring the concepts from the world of literature to that of teachers and students, which in

${ }^{1}$ Cf. Wegerif 2017 for a broader overview. I will not discuss differences between approaches to dialogic pedagogy, education or teaching, but rather refer to them as a field of research sharing a more or less deep association with Bakhtin and his dialogism. 


\section{Dialogic Discourse Analysis: A methodology for dealing with the classroom as a text}

Atle Skaftun

itself is an indication of the inspirational powers across domains in Bakhtin's philosophy. Increasingly, however, educational research has displayed an interest in exploring the connection and transferability between the domain of literature and that of education (cf. Matusov, 2007). A paradigmatic example of this turn might be the not yet finalized debate on the concept of authorship (cf. Lensmire, 1997; Matusov \& Myiazaki, 2011; Sullivan, 2014) and the relationship between author and hero transferred from the study of novels to the study of classrooms (Brandist, 2011). Also, in the study of classroom discourse Bakhtinian concepts has shown themselves useful, particularly his distinction between the authoritative and the internally persuasive word (Bakhtin, 1981, p. 342) and the general insight that words are inhabited by voices and thus that utterances and texts ${ }^{2}$ can be conceived of as instances of the general heteroglossia surrounding us.

Bakhtin is a source of inspiration in the sense that he provides us with theoretical concepts, and increasingly we also see an interest in how he performs his analyses (cf. Matusov et al., 2019) ${ }^{3}$. This article will be an attempt to bring us closer to Bakhtin's analytical practice and his methodology. I will explore and elaborate the typology of discursive relations which are suggested in Bakhtin's book on Problems of Dostoevsky' Poetics (Bakhtin 1984), and the potential application of it in the study of discourse in the classroom. In order to do so properly it will be necessary to activate Bakhtin's understanding of the utterance as a meaningful unity, and thus also the problem of authorship and the relationship between author and hero. This means cross referencing texts that are written by Bakhtin over a timespan of approximately 50 years. I will do so in concordance with Holquist's understanding of Bakhtin's authorship as a study of Dialogism (1990) and Morson \& Emerson's (1990) emphasis of dialogue as a "global concept" alongside prosaics and unfinalizability.

Bakhtin's analytical practice can be considered a consistent methodology for the study of literature in schools as well as in research (cf. Skaftun, 2009; 2010), and I have called it dialogic discourse analysis (DDA). My ambition here is primarily to elaborate DDA as a powerful and dynamic toolkit also for educational research. The moment we enter a classroom we are situated in a complex field of discursive relations, whether it is a new class getting to know each other and the teacher, or a class where dialogic relations have developed over the course of many years. Different authorial intentions might be at play simultaneously, and there might be friendly or hostile or any other kind of relation between these positions as they co-create the discourse of the classroom. Teachers have a professional responsibility for authoring the classroom as a learning environment, whereas students more or less consciously author their own learning or even their future (cf. Matusov, 2011, Matusov et al.,2016). In the live events of the classroom they participate in action authored partly by themselves and partly by others. The observing researcher enters this complexity, and responds to it in the moment of ongoing lessons, and also later on, looking back and reflecting over the experience while completing field notes and writing memos, and even later, when making use of these notes in a process of analysis and writing.

Talking about authorship in the classroom implies analogies between the study of texts and the study of meaningful action. In what follows I will explore these analogies and make the case for Bakhtinian

\footnotetext{
2 I will elaborate Bakhtin's definition of the utterance as we find it in his essay on "The problem of Speech genres" (in Bakhtin, 1986) later (see "The utterance and dialogizing background revisited". For now it is sufficient to accept that an utterance might be brief or very long, and it might be spoken or written. The spoken utterance is the primary model also for dealing with written texts in Bakhtin's dialogism. As we will see, his definition of the utterance is not at odds with a common sense understanding of the term. It is rather a matter of theorizing the common sense understanding.

3 There is an apparent overlap between my approach and that of Matusov et al (2019), particularly in the titles, but also a distinct difference. My article elaborates Bakhtin's methodology conceived of as dialogic discourse analysis, whereas Matusov et al. (2019) discusses dialogic analysis in education against discourse analysis as an established, predominantly linguistic field of research. Thus, there is a difference in interest in the overall arguments.
} 


\section{Dialogic Discourse Analysis: A methodology for dealing with the classroom as a text}

Atle Skaftun

DDA in the study of classroom action. ${ }^{4}$ The argument falls in two parts: I will first establish what DDA represents in Bakhtin's analytical practice, before applying DDA to an example from classroom fieldwork, in order to illustrate key features of DDA more than making claims for a completed analysis. In doing so I hope to contribute to the ongoing work of transferring Bakhtin's dialogism as a whole from the study of literature to the study of education, with a particular focus on authorship and Bakhtin's theory of the utterance.

\section{Dialogic discourse analysis in Bakhtin's work}

\section{Dialogue in three distinct senses}

Dialogue and dialogic is used with different meaning in Bakhtin's thinking. Morson and Emerson provide us with a meaningful sorting out of three such meanings on different levels of abstraction (Morson \& Emerson, 1990, p. 130 f.).

In the first sense, Dialogue is a metaphorical model of the human life world, and as such it is used to comment on cultural relations, history and the relations and interactions between people. His famous model of the interplay between the centripetal and the centrifugal forces (Bakhtin, 1981, p. 270ff.) points towards the struggle between the given openness of the world as dialogue, and cultural and ideological forces working to gain control and monologic authority in a messy world. The metaphor compares forces maintaining an orbit to cultural forces working towards centralizing order and de-centralizing disorder, and as such the model tells us that balance between these forces - the centripetal force of monologization and the centrifugal force of dialogization -is essential.

In the second sense, dialogue more concretely concerns language conceived of in a way that we have learned to identify as discourse..$^{5}$ Any utterance is itself part of the chain of speech communication, which is at the same time reflected within the utterance as a whole (Bakhtin, 1986, pp. 92-93). To Bakhtin the words we use are always used by others before, and thus they carry with them meaning ascribed to them by others. Language as such (i.e. as it used to form utterances) is populated by alien voices:

[...] any word exists for the speaker in three aspects: as a neutral word in language, belonging to nobody; as an other's word, which belongs to another person and is filled with echoes of the other's utterance; and finally, as my word, for, since I am dealing with it in a particular situation, with a particular speech plan, it is already imbued with my expression (Bakhtin 1986, p. 88).

This quote describes in a characteristic way Bakhtin's understanding of the utterance and of language in use as inherently dialogic. But this dramatic structure also prepares the third sense of dialogue and dialogic, which is tied to potential conflict and tensions, and thus to the intentionality or speech plan of the voices involved. Within the discursive world, we meet again the struggle between dialogic and monologic forces, similar to the struggle between openness and authoritative finalization on the global level. An utterance might be more or less dialogic or monologic, and in Bakhtin's dialogic philosophy any

\footnotetext{
${ }^{4}$ In his essay "The model of the text: Meaningful action considered as a text" (1981)Paul Ricoeur reminds us of the important distinction between written texts and meaningful action, particularly that texts have authors whereas meaningful action is open-ended until it is described and textualized. Bakhtin's dialogism represents a framework where authorship is a meaningful category also in the openended lifeworld, not the least in education. Nevertheless, we might gain from following the example of Ricoeur and make the model explicit.

${ }^{5}$ We should keep in mind that Bakhtin's work on dialogic aspects in literature and in everyday language predates the birth of discourse analysis, or the "discovery" of discourse as social phenomena and object of scientific interest.
} 


\section{Dialogic Discourse Analysis: A methodology for dealing with the classroom as a text}

Atle Skaftun

utterance is conceived of as a discursive micro world of its own, ${ }^{6}$ whether it is a brief rejoinder in a dialogue or a complex aesthetically elaborated representation of voices that we might find in a novel (Bakhtin, 1986, p. 60f.). When we are talking about dialogue in the third sense - as opposed to monologue - we must bear in mind that we are talking about concrete utterances with their specific authors, and more specifically how authors and speakers relate to the words and meanings of others.

\section{Dialogizing background and the relationship between author and hero}

In order to proceed in the exploration of dialogue in the third sense, we must address the relationship between author and hero, or more generally, the relationship between the author of any utterance and other speaking persons that appear in the utterance. They do so when the author talks about them. Meanings and thoughts, too, will be verbalized by the author, who thus might manipulate how the thought, meanings and words of others are conceived:

The following must be kept in mind: that the speech of another, once enclosed in a context, is - no matter how accurately transmitted - always subject to certain semantic changes. The context embracing another's word is responsible for its dialogizing background, whose influence can be very great (Bakhtin, 1981, p. 340, my emphasis).

The single utterance thus provides a new context - or background - for the words and meanings of others. ${ }^{7}$ The author of the utterance controls this background, and he or she ${ }^{8}$ can manipulate it according to how she wants the listener or reader to perceive the other person. Thus, an endless spectre of possible dialogic relations are available. The author can be friendly or hostile, explorative or exploiting, in agreement or not etc. The relationship can be simple to grasp and describe, or it can be a highly complex one involving layers of cognitive, emotional and ideological (or axiological) meanings and tensions. As authors of utterances in our everyday life we all provide dialogizing background, even if the power and influence vary a lot. We will return to how this perspective might apply to educational contexts, but before we do so, we should elaborate how Bakhtin makes use of this perspective in his reflection on literature.

The control over the dialogizing background concerns what Bakhtin calls an "essential surplus of meaning" on the hands of the author in his book on Dostoevsky (Bakhtin, 1984, p. 73). Bakhtin contrasts Tolstoy and Dostoevsky as monologic and dialogic authors respectively, based on how they use this surplus. Tolstoy's authorial position is rooted in tradition, and Bakhtin sees him as the loving authoritative father, that holds the narrated world together. Dostoevsky's innovation is that he finds "a new integral ${ }^{9}$ view on the person [...] possible only by approaching the person from a correspondingly new and integral authorial position" (Bakhtin, 1984, p. 58; original italics). What characterizes this position is that it makes it possible for Dostoevsky to "renounce" essential surplus and monologic premises in general (Bakhtin, 1984, p. 52) so that the represented person and the zone of discourse surrounding him gains a relative independence from the potentially all-seeing authorial eye. ${ }^{10}$ The result is what Bakhtin calls the polyphonic

${ }^{6}$ Cf. also the final words of Vygotsky's Thought and Language (1986, p. 256): "A word is a microcosm of human consciousness" and Wertsch's (1991) understanding of the relationship between Bakhtin and Vygotsky; that Bakhtin starts working where Vygotsky stops.

${ }^{7}$ Cf. Van Leeuwen appropriation of Bernstein's concept re-contextualization (Van Leeuwen, 2009).

${ }^{8}$ For the purpose of simplicity and clarity, in the following I will use she instead of he or she when referring to authors in general.

9 "Integral" here might cause some confusion. It is perhaps more often used in combinations like "integral part of", thus pointing towards essential parts, rather than the whole containing the parts or keeping them together. I think that we here must understand "integral" as a reference to the whole of the hero created by the author, and also the authorial position as a whole, which allows the author to create and also to set free his characters. The relation between the two is thus a relation between two integral subjects.

10 "The all seeing authorial eye" is a metaphor, and it is consistent with Bakhtin's own metaphorical exchange between his early approach to human action and aesthetic activity (Bakhtin, 1993; 1990) which has been characterized as a "phenomenology of seeing" 
novel, well aware of the limitations in the metaphor. The point he wants to emphasize, is that Dostoevsky found a way to represent the open-endedness of human life, conceived of as open-ended prosaic discourse and an infinity of relations between voices.

In describing this open-ended representation of prosaic discourse Bakhtin find his way into a methodology. Holquist (1990) calls it dialogism - or architectonics of relations. Morson and Emerson calls it prosaics in order to emphasize that his study belongs to the sphere of the prosaic word and that of prose fiction rather than poetics. To me it also seems fair to explore his dialogic approach to discourse analysis on its own terms. In doing so we will start with the Dostoevsky book, where he identifies different types of discursive relations in a more systematic way than often is the case.

\section{Bakhtin's typology of discursive relations: A basis for dialogic discourse analysis}

Bakhtin identifies three main types of discourse in chapter five of the Dostoevsky book: 1) unmediated, direct discourse; 2) objectified discourse; and 3) double-voiced discourse. The first type is oriented towards the referential object only, and not towards the speech of others. The second and third type both have a twofold direction: "it is both directed toward the referential object [...], and toward another's discourse, toward someone else's speech (Bakhtin, 1984, p. 185).

Objectified discourse (type two) is most typically to be found as the direct speech of the characters. The person being quoted is oriented toward the referential object, whereas the author representing his speech uses his words as an object in order to characterize him individually or as part of a social group. There is a twofold direction in the discourse of the author, but the author does not relate to the speech of the other person as live discourse representing another subject. As such it is not a dialogic relation; "The relation to the thing (in its pure thingness) cannot be dialogic (i.e. there can be no conversation, argument, agreement, and so forth)", Bakhtin says (Bakhtin 1986, p. 121). ${ }^{11}$ Dialogic relations are possible only between subjects, not between subject and objects.

Discourse of the third type concerns such dialogic relations, and is as such the chief subject of Bakhtin's investigation into Dostoevsky. He establishes three sub categories of discourse. The first two are defined by the orientation of the authorial intention relative to the intentionality of the represented words of another. Bakhtin calls them unidirectional and vari-directional double-voiced discourse (cf. category II1 and III.2 in table 1). Both of these types will in one way or the other provide concrete references to the words of the other, so that it is a matter of representation. Unidirectional and vari-directional here simply refers to whether the internationalities at play - those of the author and the speaking persons being represented are aligned or deviant. Agreement and disagreement are illustrative examples, but the range of possible relations is wide and deep, particularly when in the field of vari-directional discourse. Irony and parody are prominent examples of vari-directional discourse, which can be playful or harsh, friendly or hostile, recognizable in the utterance on the basis of subtle nuances.

(Gemzøe, 1998; 2001; Skaftun, 2003, p. 32, n; White, 2016), and his discovery of discursive representation of dialogic relations in Dostoevsky's poetics.

${ }^{11}$ In «From Notes Made 1970-71» Bakhtin lists three types of relations: 1) between objects, 2) between subject and object, and 3) between subjects (Bakhtin, 1986, p. 138), which appears all through his authorship. 
I. Direct, unmediated discourse directed exclusively toward its referential object, as an expression of the speaker's semantic authority

II. Objectified discourse (discourse of a represented person)

1. With a predominance of sociotypical determining factors

2. With a predominance of individually characteristic determining factors

Various degrees of objectification

III. Discourse with an orientation toward someone else's discourse (double-voiced discourse)

1. Unidirectional double-voiced discourse

a. Stylization;

b. Narrator's narration;

c. Unobjectified discourse of a character who carries out (in part) the author's intention;

When objectification is reduced, these tend toward a fusion of voices, i.e.

d. Ich-erzählung toward discourse of the first type.

2. Vari-directional double-voiced discourse

a. Parody with all its nuances;

b. Parodistic narration;

c. Parodistic ich-erzählung;

d. Discourse of a character who is parodically represented;

e. Any transmission of someone else's words with a shift in accent;

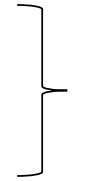

3. The active type (reflected discourse of another)

a. Hidden internal polemic;

b. Polemically colored autobiography and confession;

c. Any discourse with a sideward glance at someone else's words;

d. A rejoinder of a dialogue;

e. Hidden dialogue
When objectification is reduced and the other's idea activated, these become internally dialogized and tend to disintegrate into (two discourses) of the first type.

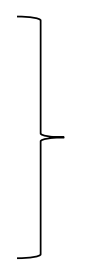

The other discourse exerts influence from without; diverse forms of interrelationship with another's discourse are possible here, as well as various degrees of deforming influence exerted by one discourse on the other

Table 1: Bakhtin's typology of discourse (Bakhtin, 1984, p. 199) ${ }^{12}$

In the last sub category - the active type, or the reflected discourse of another (cf. category III. 3 in table 1) - we don't find any explicit representation of the words of the other. Nevertheless, the author more or less clearly relates to another speaker, be it as a response or anticipation of future response. The discourse of another has influence on the author from without. The isolated rejoinder in a dialogue is probably the best example to illustrate this category at this point. With that as a model we might think of more subtle examples, where we speak under the influence of alien discourse, be it past or future, friendly or hostile, interested or disinterested etc. We will explore these categories more in depth as we apply them to educational contexts, but before we do so, we might benefit from an excursion into Bakhtin's more general discussion of live speech and the utterance as the unit of investigation.

\footnotetext{
12 The complete table makes visible the main categories, which is immediately helpful. The comments on degrees of objectification is perhaps not immediately meaningful. I have included them in order to display the wholeness of the only occurrence to my knowledge of the table format in Bakhtin's writing. The types of relations listed in footnote 10 might be helpful; "objectification" introduces a dynamic field between the isolated types of relation (subject-subject and subject-object).
} 


\section{Dialogic Discourse Analysis: A methodology for dealing with the classroom as a text}

Atle Skaftun

\section{The utterance and dialogizing background revisited}

In The problem of speech genres (Bakhtin, 1986) Bakhtin defines the utterance by identifying three features that makes it a whole, meaningful unity. First: It is framed by the change of speaking subject, and thus has a "stable mass that is sharply delimited from other related utterance". ${ }^{13}$ Second: The utterance is always finalized, thus making it possible to respond to it. "The finalization of the utterance is, if you will, the inner side of the change of speaking subjects", Bakhtin says (1986, p. 76); it concerns the thematic, intentional and compositional unity of an utterance. Third: The utterance is also a relational whole, defined by its relation to the theme (referentiality), the author (the expressive aspect) and other (past, present and future) participants in the communication (addressivity) (Bakhtin, 1986, p. 84ff.). The utterance as a whole, a unity, ${ }^{14}$ is part of a macro cosmos of utterances in a particular sphere linked together in a chain with no beginning and no end (Bakhtin, 1986, p. 191). At the same time, it can be seen as a micro cosmos of interacting voices and perspectives.

The third category in the scheme from the Dostoevsky book applies primarily and most concretely to the novel (and correspondingly, the utterance) as a micro cosmos of voices, utterances and social languages. ${ }^{15}$ Double-voiced discourse are utterances where the author addresses another's discourse. In the essay on speech genres he describes it as follows:

It is as though the change of speech subjects has been internalized. The boundaries created by this change are weakened here and of a special sort: the speaker's expression penetrates through these boundaries and spreads to the other's speech, which is transmitted in ironic indignant, sympathetic, or reverential tones [...] (Bakhtin, 1986, p. 92).

Further, the utterance as such is always created by an author, independent of the genre and independent of whether the utterance is written or spoken. There are of course differences between everyday communication and novelistic prose. The novel might have as an objective in itself to represent the world surrounding people, talk and action, whereas communication is more likely to make use of representation as a means to an end. Nevertheless, this is a difference in degree rather than an essential difference. Forms for representing the words of others are important in everyday life as well as in novelistic prose (Bakhtin, 1981, p. 337ff.):

The topic of a speaking person has enormous importance in everyday life. In real life we hear speech about speakers and their discourse at every step. We can go so far as to say that in real life people talk most of all about what others talk about - they transmit, recall, weigh and pass judgement on other people's words, opinions, assertions, information; people are upset about by other's words, or agree with them, contest them, refer to them and so forth (Bakhtin, 1981, p.338).

Three important points can be made following this quotation. First, it reminds us that we respond to representations of other people as speaking persons in everyday life, similar to what is the case when

\footnotetext{
${ }^{13}$ The utterance as a unit in speech communication is fundamentally different from the sentence as a unit of language (Bakhtin, 1986, p.73ff.).

${ }^{14}$ These three features evoke his focus on The problem of material, content and form (cf. Bakhtin, 1990): The utterance is considered as a whole, a unity, from different perspectives, we might say - as physical material, as immaterial content and finally as relational (architectonic) form - in the essay on the speech genre.

15 If we acknowledge this, it has important implications for how we might apply in an analysis of the classroom. We will return to later under the heading "The classroom as a text".
} 


\section{Dialogic Discourse Analysis: A methodology for dealing with the classroom as a text}

Atle Skaftun

we read a novel. ${ }^{16}$ Second, the kind of talk Bakhtin mentions is played out in conversational settings, but the basic unit of analysis is the utterance and the discursive life that goes on within the border of single utterances. Transmission, weighing and judging the words of others are authorial actions; it concerns how the author of the utterance relate to the speaking person he is referring to. Hence, the third point is a reminder that we keep in mind that every utterance necessarily has an author responsible for the dialogizing background. There is an infinity of possible relations between an author and his hero, or rather, the words of another speaking person, and dialogic discourse analysis is concerned with grasping and describing this field of relations.

\section{DDA applied to educational settings}

Transferring these three points to the study of meaningful action, we face some challenges. In general, there is the fact that we are applying a model based on the study of literature and texts to openended meaningful action, thus necessarily making use of inferences that will be based on the work of conceptual metaphors. The conception of authorship is the most prominent of these metaphorical features. The concept of dialogizing background will be particularly useful in what follows. I will introduce an example displaying an experience of classroom discourse, before moving on towards reflections over authorship and a conception of the classroom as a text.

\section{An experience of discourse in the classroom}

Let us consider an example from an observational case study of digitalized secondary classrooms (the Response-project, cf. Igland, Skaftun \& Husebø, 2019; Skaftun et al., 2017). The research team followed five classes through Year 8-10 (students aged 12-15), which is the lower secondary school level in Norway. I observed 36 lessons across all subjects in one of these classes. The main interest in the project was whether or how digital technology might contribute to dialogic space calling for students' responsive and responsible action. Classroom discourse as such was not the primary interest in the Response-project, and we made neither audio nor video recordings. Nevertheless, overall relational and discursive features were prominent in my field notes and memos from the early stage of the fieldwork. First or early impressions like these clearly have their limitations, but they are both important and interesting as the researcher's immediate response to the classroom as a textual whole, to be tested, revised and analyzed over time.

After one of my first visits (November the fifth, 2014) in 8A at the South East School I summed up fieldnotes and reflections, and included a memo on classroom culture:

There are 9 boys and 4 girls in the class this day. The boys dominate the classroom before the teaching starts as well as when it is ongoing, whereas the girls seem quite passive. It is possible that this is because the 3 girls missing - this must be considered later on in the fieldwork. In talks with involved teachers during the day, I searched for their judgment, but they did not seem to think in categories like these, even if the math teacher actually talked to two of the boys in the break about their "cantankerous" behavior. Maybe I am wrong.

Nevertheless: My impression is that there is a distinct student discourse in the room, which in a subtle way opposes the discourse of school and learning. This discourse is characterized by a constant ironic displacement of focus - it is tempting to see it as parodistic discourse: The students performing the parody engage in what is going on in the classroom, but they relate to a distorted image of the disciplinary intentions underlying the ongoing work. This is not about school hostility as

\footnotetext{
16 Bakhtin acknowledges the complexity and open-ended vitality of the discursive lifeworld as a source of inspiration for the
} development of the novel as a genre. 


\section{Dialogic Discourse Analysis: A methodology for dealing with the classroom as a text}

Atle Skaftun

such, I think. Quite the opposite, actually: I sense an intellectual undertone in the distancing to the disciplinary discourse, as if they call for resistance. The group work on arguments for and against Halloween [a foreign tradition imported to Norway] is a clear example: Most of the boys accept that they are going to find arguments and that they are supposed to for or against, but beyond that they establish a quasi-discussion, where the main point is to create witty and funny phrases.

Subtler, perhaps, are the negotiations on how to write full answers to text-based tasks in math in the first lesson of the day. There is nothing new in students wondering what's the point with a lot of things in school. Here, however, it seems that there is something else or more at stake; smart and clever students seem to call for verbal struggle and argumentation. At one point during the day, I associate this phenomenon with "posh brats ["silkeramp"]. The student discourse is a way of positioning students, and at the same time, it positions teachers, subject matter and school as teacher governed, with no interest in what students actually think and know, etc. When teachers do their best at meeting the students on their turf, the students have already defined them as not interested in dialogue with students. We might say that the student discourse is a response to such an image of the discourse of school and teachers; what happens in the classroom is a continuous not-meeting (My field diary, November the $5^{\text {th }}, 2014$ ).

The memo lacks support by means of transcriptions, but it is nevertheless a concentrated, descriptive and interpretative representation of speaking persons in $8 \mathrm{~A}$ based on being present in the classroom; it is a representation of the classroom against a dialogizing background rooted in my experience of the classroom. Over the course of three years, the somewhat subversive energy emphasized in the memo faded out and the students were more concerned with grades and performing according to standards. It might be that I was actually wrong, and thus that the teachers, who did not quite recognize the subversive forces at play, were right. But it might also be that I, from my vantage point of view as unfamiliar with the class, perceived something that the teachers did not see or hear. It might be that I was hypersensitive, but it also might be that the teachers were deaf to the subtle parodistic play in the student responses to tasks and questions. This is a question with methodological implications, concerning both the value we ascribe to first impressions and to descriptive interpretations. The gap between my understanding and that of the teachers is in itself an observation that calls for attention.

The memo concerns what happens in a classroom over the course of several lessons in an ordinary school day, not the more or less dialogic purpose of the teachers, nor the kind of questions they are asking. Rather than representing ideal learning trajectories, as is often seen in research on dialogic teaching, the observed lessons are drawn from the everyday life of normal classrooms. Let us take a closer look at one of the lessons referred to in the memo.

The mathematics lesson consists of two 45-minute sessions separated by a 15 minutes break between 0815 and 1000 in the morning. The first session consists of four main activities in addition to practical information, followed up by seat work with tasks on the new subject of the day in the second session (see table 2). The teacher - let us call her Mary ${ }^{17}$ - was in her early thirties at the time of the observation, which was the only time I met her; the next time I observed mathematics, a new teacher had taken her place.

\begin{tabular}{|l|l|}
\hline 0815 & Practical information \\
\hline 0822 & 1: Writing complete answers to text-based tasks \\
\hline
\end{tabular}

${ }^{17}$ Locations and people are anonymized by means of fictional names 


\begin{tabular}{|l|l|}
\hline 0832 & $\begin{array}{l}\text { 2: Math quiz; } 12 \text { tasks to be worked out in the head and written down on pieces of paper } \\
\text { handed out) }\end{array}$ \\
\hline 0844 & 3: Review of the answers \\
\hline 0852 & 4: New subject: Number lines \\
\hline 0900 & Break \\
\hline 0915 & Introduction to seatwork on number lines \\
\hline $0920-1000$ & Seatwork with tasks on number lines \\
\hline
\end{tabular}

Table 2: Overview of activities in the mathematics lesson

I had the impression that Mary sincerely wanted to reach out to the students. The first activity is partly motivated with reference to test demands - the fact that incomplete answers to text-based tasks will not be considered correct - but there are also references to important conventions of mathematics as a discipline. To some extent, she argues the case of disciplinary thinking, rather than the case of authoritative disciplinarity, we might say. Some of the clever boys also seem to identify with mathematics as a subject, even if they do not align with their teacher. "We could have done that in the head", says Ben, f.ex., and Mary makes the point that "You have to show them how you think". They continue through several examples, and the resistance persists. "It's OK to do it once, but doing it 17 times...", Ben says, and Mary defends the activity by emphasizing the importance of learning routines through simple tasks. This negotiation of a disciplinary literacy practice starts out as an invitation into dialogue, but it develops into more of a positioning game. In the end, Mary stops the discussion by saying that she defends the value of complete answers in general, and not the least in order not to lose points in tests and assessments. As she is saying this, she is literally standing alongside the written answer on the blackboard with her arms crossed over her chest.

Also, in the next activities - performing and reviewing a set of tasks to be worked out in the head there is a buzz of cantankerous discussion. Increasingly, the boys seem impatient and bored, and not acknowledging towards the disciplinary capacity of the teacher, thus leaving the scene open for subversive voices. In my field notes, I noted the abundances of pedagogical moments in this lesson, but gradually, the negative forces took over.

It is particularly one of the boys, Andrew, who plays this part, and most prominently in the last activity before the break, in which number lines are introduced as a new topic. When the plenary talk touches upon the use of signs for less than $(<)$ and greater-than $(>)$, he starts talking about them as "crocodile signs", which is a term the teacher has used once during the quiz review in order to explain the logic of them. Andrew, however, activates the term as a simplified, childish term, and relates to it as if he is playing along, being the child which allegedly the teacher has positioned him as. In this case we see parodistic discourse directly attacking or even mocking the teacher.

If we set aside the uncomfortable and somewhat mean aspects of what Andrew is doing, we see quite complex communication. Andrew answers to the teacher initiative, and seemingly he accepts the position made available for him by the teacher and the predominant IRE-like speech genre of school (cf. Mortimer \& Scott, 2003). As such his answer is framed by the institutional talk of the teacher. By means of parodistic distance, however, his utterance becomes the frame in which the talk of the teacher, the speech genres in school, as well as the discursive position available for students in school is represented and commented on.

Andrew activates what might be called a subversive speech genre which is established in the class, and which is associated with a parodistic register of talking, or of discourse. This genre and the corresponding discourse seem to represent a framework for vari-directional response to dominant 


\section{Dialogic Discourse Analysis: A methodology for dealing with the classroom as a text}

Atle Skaftun

discourses in school. We might say that the parody shows itself as playing along with the expectations of the IRE-structured discourse, while at the same time displaying consciousness of playing along with no deeper interest. If this makes any sense, then it might also explain why the teachers does not sense the double voiced activity in class; they are inhabitants of the discourse that is the object of parody and not prepared to detect signals of distance towards it. Alternatively, they do sense the hostile tendency, but consider it part of business as usual. Or perhaps they do sense it, but are not ready to talk about it with me as alien researcher.

Dialogic discourse analysis provides us with tools to describe the relational dynamics of real-life classroom interaction. The example above displays the classroom as a field of discursive struggle. DDA as applied here doesn't solve the problem, but rather helps us to recognize it as part of the classroom culture and practice. The teacher has a position in the present of the ongoing lesson, and will have to deal with challenges and subversive initiatives from moment to moment. Teachers and students alike are continuously authoring the situation (cf. Matusov et al., 2016), mutually responding to each other. The teacher authors a learning situation where the students are invited into substantial engagement. Prominent students on the other hand, relates to a distorted version of the teacher intention, thus authoring a parodistic counter discourse which dominates the classroom.

Vari-directional discourse can be playful and witty and it is indeed a situated phenomenon to be interpreted as such. The Danish poet Piet Hein might be an important reminder to us about the interdependency of seriousness and play:

Taking fun as simply fun and earnestness in earnest

shows how thoroughly thou none

of the two discernest

(http://www.sophilos.net/GrooksofPietHein.htm )
Den som kun tar spøg for spøg

og alvor kun alvorligt

han og hun har faktisk fattet

begge dele dårligt

(Hein, 1940)

A dialogic approach to understanding what is actually going on in the classroom provides us researchers and teachers - with a sensitivity for the classroom as a relational complex; we are making use of dialogism as relational architectonics, with the words of Michael Holquist (1990).

Maureen Boyd and William Markarian (2011) make the case for a "dialogic stance" in a teacher that doesn't appear very dialogic based on transcripts from his lessons. They analyse a seven minutes teaching sequence, where the teacher challenges the students and says things that taken in isolation would seem quite direct and authoritative. In the situation, though, the students accept this tone and addressivity, and they respond as part of a meaningful event. Boyd and Markarian provide contextual support for this claim, by observing the classroom over a long period of time. The main point, however, is that dialogic stance cannot be grasped on the basis of linguistic form and structure alone. We sense the author in the whole of a novel. This is the case also of the classroom as authored by the teacher.

\section{Authoring and the problem of the text}

The idea of authorship linked to dialogizing background enables us to see discursive relationships within single utterances and between utterances over different time spans. The two levels - that of concrete dialogic exchange and that of the inner life of the single utterance (or the text) - mutually shed light on each other. We can study single utterances (texts) as if they contained dialogic interactions, and, the other way around, we can study interaction and situations as texts. We do that when we turn meaningful action into a 


\section{Dialogic Discourse Analysis: A methodology for dealing with the classroom as a text}

Atle Skaftun

textual representation (cf. Ricoeur, 1981) or with the words of van Leeuwen, practice into discourse (van Leeuwen, 2008). Shifting between these perspectives provides us with metaphors and analogies.

One such metaphorical use of Bakhtin's theory of the utterance, is to consider the classroom as a text, with one or more authors and perhaps also a reader (or listener) in the form of the observing researcher present in the classroom. I realize that the analogy has its limitations, but it seems appropriate to widen the perspective in order to get a grip of the larger dialogizing background of what goes on in a classroom. It is also an understanding which is at work implicitly in the discussion of authorship in educational contexts (Lensmire, 1997; Matusov, 2011; Matusonv \& Miyazaki, 2014; Miyazaki, 2011).

Lensmire (1997) was the first to compare the role of the teacher with that of an author within the field of dialogic pedagogy. More specifically he outlines how "the teacher as Dostoevskian novelist creates a classroom novel and takes up relations with student-characters", with reference to writing workshops in elementary and secondary classrooms. Miyazaki, similarly, sees the teacher as the author of a polyphonic novel, and correspondingly, the students as heroes of the created learning space:

Children in the Saitou classroom can be compared to the heroes of a polyphonic novel. Contrary to heroes in a monologic novel, in the polyphonic novel, heroes generate voices new even for their author, and can oppose the author. However, it is the author who controls the heroes' behavior. This is similar for the Saitou teacher. Children become dialogic learners only via the teacher's interaction with them (Matusov \& Miyazaki, 2014,p. 36)

Matusov (2011) "respectfully disagrees" with these claims, and more specifically with the idea that teachers author students. Even if characters in a novel can surprise their authors, these characters "remain transparent to the authors who are their creators", he says (p. 40), and he continues:

Students are not creations of their teachers, they do not unconditionally cooperate with the teacher's plot (or the "logic" of the emergent plot), they have voices that the teachers do not have, and they are not transparent to the teacher's comprehension and imagination. [...] There is only one legitimate author of the student, namely the student him or herself as unique, limitless, unfolding universe (Matusov, 2011, p. 40).

Where Lensmire and Miyazaki see students as authored by the teacher, Matusov see students becoming authors on their own, and "Authorial teaching and learning" as a matter of student agency conceived of as authorship. There are (at least) two objections in this passage, both of which directly rejects Bakhtin's positions rather than that of Lensmire and Miyazaki.

The first objection is that students should be their own authors, conceived of as "unique, limitless, unfolding universe". Matusov (2011) finds the idea that teachers author students a scary one, and it seems that he, in order to free the students from the authorial powers of the teacher, is willing to abandon Bakhtin's general idea of authorship within a shared human life world. According to Bakhtin we author each other, and we need the authorial position of others in order to become and see ourselves as subjects. As subjects, we all have a unique place in the world, ${ }^{18}$ i.e. in the same world. Creating our own worlds, however, would

\footnotetext{
${ }^{18}$ Bakhtin calls it "the unique and unified event of being" (Bakhtin, 1993). It is unique in the sense that only the individual subject can fill this place, and it is unified since we all have such a place in the world.
} 


\section{Dialogic Discourse Analysis: A methodology for dealing with the classroom as a text}

Atle Skaftun

lead us all into isolated filter bubbles (cf. Pariser, 2011) or even solipsism. Thus, if we push the logic of Matusov's statement, we end up in a conflict with basic ideas in Bakhtin's dialogism.

The second objection is simply a rejection of Bakhtin's conception of the polyphonic novel without any comment. Bakhtin's point in the Dostoevsky book is that it is possible to represent a speaking person while at the same time letting the person retain the final word about himself (Bakhtin, 1984, p. 53). He talks about the "freedom of the character as part of the author's design" (p. 65) and about "the relative independence of characters with the limits of Dostoevsky's creative design" (p. 64), mainly based on the fact that, "for the author the hero is not a "he" nor an "I" but a fully valid "thou", that is, another and autonomous "l" (Bakhtin, 1984, p. 63). Matusov rejects this idea, and in its place, he puts the monologic conception of the novel with its omniscient author. ${ }^{19}$

Dostoevsky found a creative design that enabled him to bring the novel closer to being in the prosaic world, we might say. Similarly, when we are talking about dialogic teaching, we are often dealing with pedagogical designs that might enable us to bring teaching closer to a sense of conversation in everyday life (cf. Nystrand \& Gamoran,1991). The polyphonic novel is a meaningful conception of novelistic innovation when it is contrasted to traditional forms. Similarly, dialogic teaching is still teaching - it is still part of the architectonics of education - but it provides the teacher with a new integral position relative to that of his classroom and his students. It wouldn't be entirely wrong to say that the very heart of dialogic teaching is - or should be - relating to the student as "a fully valued thou" (i.e. a subject - subject-relation), and thus providing them some relative independence and freedom.

Students and teachers may all contribute to authoring the classroom. When things are working well, students author themselves and the classroom in a way that is compatible with the overall pedagogic and didactic design authored by the teacher. Nevertheless, teachers have a responsibility for the classroom as a whole, similar to the authorial responsibility for the utterance as a whole. Teachers make plans for each lesson and the progression of lesson on both short term and for the whole school year, and they often reflect on what actually happened during a lesson afterwards. The teacher thus has an authorial position outside the classroom as a textual whole, from where he or she ${ }^{20}$ can manipulate the dialogizing background and create dialogic space (Wegerif, 2007). The teacher is, however, also present in the open ended here and now of the classroom. The degree of openness tied to this presence is thus an important part of the pedagogic design. Making open ended space for student participation in open ended events implies that the teacher must include uncertainty and risk as part of their design, and also accept being in uncertain and risky situations in the present of their lessons. The teacher is thus both an author of the classroom as a text, and a character in this text. ${ }^{21}$ The really flexible "reflective practitioner" in Donald "Schön's terms (1983) is able to shift between these two positions on the spot.

We need an understanding of the classroom as textual space where dialogic relations are played out. This space can be designed in different ways just like novels can be created in different ways. The pivotal point of both literary and pedagogical designs is how the dialogizing background for concrete events and utterances is formed and administered. I 8A, as I experienced it early autumn 2014, there was open struggle about the control of this dialogizing background, we might say. The subversive energy disappeared

\footnotetext{
19 Marjanovic-Shane (2014) makes the point that Miyazaki and Matusov are talking from different paradigmatic positions, and thus not really talking about the same thing. This is a good point, and combined with my argument, Matusov actually falls out of the dialogic paradigm. I don't think neither Matusov nor Marjanovic-Shane will agree, however, and hopefully they will respond to my challenge.

${ }^{20}$ For the purpose of simplicity and clarity, in the following I will use she in stead of he or she when referring to teachers as authors.

${ }^{21}$ Here we are entering a paradox that is a paradox also in literary theory in general as well as in Bakhtin's theories of the novel and the utterance. Autobiography as a genre for our analogy is a readily available example of the relation between authorial I responsible for the text, and the "l" represented in the text.
} 


\section{Dialogic Discourse Analysis: A methodology for dealing with the classroom as a text}

Atle Skaftun

over time, but so did energy in general. The classroom came to be emotionally flat and lifeless, and it felt like teachers and students had made a bargain, where "Teachers implicitly agree not to demand too much of the students, and students acquiesce to the standards of conduct required by teachers" (Nystrand and Gamoran, 1991, p. 3). Rather than the relative freedom of a polyphonic space, it seemed like an upsidedown world of carnival and parody, and after a while, when the carnival was over with, it turned into a copy of a monologic traditional prose story, where all elements and features are known in advance by both teachers and students.

Pedagogic and didactic design is a matter of creating and forming the textual space of interaction. Dialogic designs differ from traditional pedagogical design in that they more highly value open-endedness - or eventness ${ }^{22}$-as a feature of the classroom. Following this line of thought, designing dialogic teaching and creating classrooms that can be characterized as dialogic, is not a question about whether the teacher is an author or not, but rather what kind of author she is.

\section{Understanding author-ity}

We have pointed out that Dostoevsky's innovation was possible due to what Bakthin calls a new integral position of the author relative to the speaking person in the novel. The innovation implies a shift in the history of the novel genre, but it is also indicative of a revolting shift in Bakhtin's thinking from classical to a more modernist aesthetics, as pointed out by the Danish literary scholar Anker Gemzøe (1998). In his 1924 essay on Author and Hero in Aesthetic activity (Bakhtin, 1990) Bakhtin is concerned with authorship in general and the consummation of the subject possible only from the position of the other. Aesthetic activity is generally the act of creating wholes, which is even more important in artistic activity than in everyday life. In the last section of the essay he refers to modernist tendencies in literature, and reflects over what he calls "the crisis of authorship" (Bakhtin, 1990, pp.202-205). Stable forms associated with authorial outsidedness begin to disintegrate, he says, with Dostoevsky as a prominent example. Five years later, in 1929, the first edition of Problems of Dostoevsky's Poetics is published, in which the distribution of value is turned upside down, making Dostoevsky the hero in the story of the novel genre and the quest for representing human life. Considered as a shift, this story in itself might be worthwhile making part of educational discourse. It adds historical and cultural depth to our analogy between single authors and teachers, by situating concrete classrooms in a process of struggle between ideas and values belonging to a traditional paradigm for education and the still emerging paradigm of dialogic teaching (cf. Wegerif, 2013).

We should, however, proceed with caution about development and shifts in Bakhtin's publications. Brian Poole (2001) warns us about the great uncertainty tied to dating Bakhtin's publications, and he also argues that Bakhtin might have worked on different texts simultaneously. The most important point, nevertheless, is that Bakhtin's positive evaluation of consummation in Author and Hero can be said to complement his devaluation of finalization in the Dostoevsky book, in a way resembling the double nature of the centripetal force. The first one is concerned with authorship and the creation of meaningful wholes in general, whereas in the latter he focuses on a particular authorial position that enables the author to get closer to representing human consciousness in its here and now by more specifically entering into dialogue with them. The author is still there - it is what he does and how he does it that is new. Similarly, the teacher of the more dialogic classroom is still the teacher responsible for the whole, but she orchestrates it in a

\footnotetext{
${ }^{22}$ Eventness, a key term in dialogism, concerns the open-endedness of life and being in the world. Being as event implies that every one of us has a unique position in the continuous flow of time, and every moment we face situations that address us and call for an answer. Whether we answer or not, and how we answer does not change the fact that we are called upon to answer. This situation the unique and unified event of being (Bakhtin, 1990, p. 24) - is thus the basis for Bakhtin's conception of answerability, or responsibility.
}

Dialogic Pedagogy: An International Online Journal | https://dpj.pitt.edu DOI: 10.5195/dpj.2019.277 | Vol. 7 (2019) 


\section{Dialogic Discourse Analysis: A methodology for dealing with the classroom as a text}

Atle Skaftun

manner different from that of traditional teaching, and (at best) based on a different understanding of the teacher - student relationship.

If we allow ourselves to see both arguments as meaningful - that there is a development towards the discovery of a more dialogic form of the novel, and that Bakhtin explores different aspects of the genre over time - we have ourselves a cultural and historical framework for making use of the analogy between teachers and authors. Thus, we might also avoid the tendency to only focus on the Dostoevsky book as a source of inspiration for educational research. Bakhtin describes in detail different authorial positions, which all add substantially to the novel genre as a field of possibilities for representing the prosaics (cf. Morson \& Emerson, 1990) of human life. Tolstoy is the all-embracing, patriarchal authority, who consummates his characters with love from his outside authoritative position (cf. Bakhtin, 1990, p. 25). Dostoevsky renounces his "essential surplus" as author and leaves the final word about the hero to the hero himself (cf. Bakhtin, 1984). By situating the hero on the threshold of the present, in dialogue with surrounding voices, he managed to represent the open-endedness of life. Goethe as the master of the bildungsroman is able to create "the image of man in the process of becoming" (The Bildungsroman, Bakhtin, 1986, p. 19); whereas Rabelais celebrates and transfers the mundus inversus of carnival to literature (Bakhtin 1981, 1984b).

All of these positions (and there very well might be others given that dialogism is a way of thinking in open systems, not in closed taxonomies) are useful for different purposes, in literature, and probably also in education. An understanding of different authorial positions adds contextual depth to the understanding of classroom discourse and literacy events, and also signals that different teacher positions have different strengths and weaknesses. Every single teacher necessarily build up a register (cf. Alexander, 2008) of approaches to the class, and from that position, like an author, she will stage lessons (cf. utterances) which will be framed by recognizable genres of teaching. Thus, the teacher might turn into a stable type of a traditional teacher or a teacher inspired by modern ideas, or she might appropriate both traditional and modern approaches as a basis for shifts between different positions and communicative approaches depending on purpose and content (cf. f.ex. Mortimer \& Scott, 2003²3).

Dialogic pedagogy is a well-established idea over the course of several decades, and there is a convincing research basis documenting positive correlation between dialogic teaching and learning outcome (Applebee et al., 2003; Mercer, 1995; 2002; Nystrand, 1997; 2006; Mercer et al. 1999; Murphy et al., 2009). Rupert Wegerif suggests Dialogic to be a model of understanding for an education in the Internet age, replacing the book logic as a model for teaching and learning (Wegerif, 2013, 206). The shift towards dialogic features is increasingly expressed in official white papers, and supported by digital technology providing new dialogic space and enhancing conditions for collaboration and interaction in old ones (Major et al., 2018; Skaftun et al., 2017). Yet, we also know that realizing dialogic teaching is not easy. Teachers who acknowledge the positive effect of dialogic teaching, doesn't necessarily act on this insight in their own practice (Nystrand, 2006). Large scale implementation might end up in a superficial emphasis on student talk (Lefstein, 2008; Segal \& Lefstein, 2016), which is not any substantial step away from neither "the persistence of recitation" (Alexander, 2008, p. 47f.) nor the "lack of depth" in whole class teaching in Norwegian classroom (Hodgson et al., 2012, p. 16).

\footnotetext{
${ }^{23}$ Mortimer \& Scott (2003) operationalizes authoritative vs dialogic on the basis of whether or not the teacher relates to other perspectives on the subject matter (referential object). As such they do not address dialogic relationships in the sense suggested by Bakhtin: "Dialogic relationships are reducible neither to logical relationships nor to relationships oriented semantically toward their referential object, relationships in and of themselves devoid of any dialogic element. They must clothe themselves in discourse, become utterances, become the positions of various subjects expressed in discourse, in order that dialogic relationships might arise among them (Bakhtin, 1984, p. 183). It resembles rather what has been called linguistic polyphony (Nølke, 2017).
} 


\section{Dialogic Discourse Analysis: A methodology for dealing with the classroom as a text}

Atle Skaftun

Increasingly researchers point towards a connection between high quality dialogic teaching and the understanding of knowledge and learning that is the basis for the practices observed in school (Kuhn, 1991; Wilkinson et al, 2017). Taken together this situation resembles the "crisis in authorship" Bakhtin described in his essay on Author and Hero in Aesthetic Activity (Bakhtin 1990). Conflicting ideas and ideals of what it means to be a good teacher is at play, similar to the tension between tradition and innovation in the history of art and literature. The classical idea is deeply rooted in all aspects of the traditional practices in school, whereas the idea of the dialogic teacher is still emerging, and often reduced to the behavioral surface.

Research promoting and supporting the shift towards dialogic teaching might find authorship a useful conceptual tool in addressing and working with underlying theories of action (Argyris \& Schön, 1978) tied to classroom practice together with teachers ${ }^{24}$. And dialogic discourse analysis might be a useful analytical approach when verbalizing the relational mechanisms that holds the practice together, thus making them available for reflection and negotiations.

\section{Summing up: Methodological implications}

Dialogic discourse analysis (DDA) allows us to describe the relational complexity of the classroom. In our 8A example we have seen that there is an ongoing conflict about authorship. With authorship comes authority, which again must be used in one way or the other. In $8 \mathrm{~A}$ it seems that there was a local crisis in author-ity; students resisted being authored into a childish position, by responding childishly as if they actually accepted this position. The students relate to what we might call a "teacher voice" which we sometimes meet particularly in primary school; in my experience this stereotype of a teacher talks in a lighter tone (typical of parent - children talk) and slowly with an emphasis on every word, almost as if modelling reading to beginning readers; actually, we might say, metaphorically, that the teacher is behaving like a speaking book. It is a kind of talk that is very far from conversational flow, and there is no room for student voices nor thinking. The result is vari-directional double voiced discourse (parodistic discourse), in which the students control the dialogizing background, which undermines the authority of the teacher and thus also the teacher as responsible author of the lesson.

Focusing on the teacher in educational research is a sensitive matter, even if we know that the teacher is an extremely important factor in single events and more established practices in the classroom culture. The concept of authorship might be a useful way of drawing a line between the teacher as author and the teacher as a person. Educational researchers act like readers of a novel, and we might have an image of the author based on what we see and hear. This is a construction, however, and cannot be taken for the author as a person. "Authorship" is performed by the teacher, and responded to by the readerresearcher, who will try to grasp the classroom as a text and re-accentuate it as a meaningful whole. "Art and life are not one, but must become united in myself - in the unity of my answerability", Bakhtin says in a brief text on "Art and Answerability" probably written in 1919 (Bakhtin, 1990, p. 2). In his late essays and notes he returns to this issue, with the term "creative understanding" (Bakhtin, 1986, p.7; 142).

Doing DDA requires creative engagement in the act of understanding, and also finding an integral position from where to relate to the speaking persons in the classroom, similar to the task of the teacher and the author of novels. The descriptive account must be credible and transparent, and transcriptions of dialogic exchanges will always be valuable. But dialogic aspects of discourse are not always rendered most effectively by quoting concrete discourse (Boyd \& Markarian, 2011). It is rather a matter of ground rules (Nystrand, 1997, p. 90), of trust and respect, and taking students seriously (Kachtur \& Pendergast, 1997).

${ }^{24}$ Action theory has become a key reference in school based professional development in Norway (Postholm \& Emstad, 2014). 


\section{Dialogic Discourse Analysis: A methodology for dealing with the classroom as a text}

Atle Skaftun

The idea of student voice is not realized the moment students simply talk more. Alongside opportunity to talk (which is not a prominent feature in the typical classroom in Norway, (cf. Hodgson, 2012, Klette, 2003, Skaftun \& Wagner, 2019) they must be allowed to deal with substantial ideas, use their own language, and be acknowledged for doing so by others (Segal \& Lefstein, 2016). Bakhtin's study of the double-voiced word has taught us to consider the dialogic relations that are played out within single utterances, and sometimes, in order to verbalize or visualize such relations, we must ourselves enter into dialogue with them. The memo from $8 \mathrm{~A}$ is an example of such a response to a classroom populated by teachers and students. DDA calls for a respond towards the whole of situations and speaking persons, and also provides specific tools that might enable us to verbalize relational aspects that often determine the conditions for student engagement.

\section{References}

Applebee, A. N., Langer, J. A., Nystrand, M., \& Gamoran, A. (2003). Discussion-based approaches to developing understanding: Classroom instruction and student performance in middle and high school English. American Educational Research Journal, 40(3), 685-730.

Argyris, C., \& Schön, D. A. (1978). Organizational learning: a theory of action perspective. Reading, Massachusetts: Addison-Wesley.

Bakhtin, M. (1981). The dialogic imagination: four essays. (M. Holquist \& C. Emerson, Trans.). Austin: University of Texas Press.

Bakhtin, M. M. (1984). Problems of Dostoevsky's Poetics. Minneapolis: University of Minnesota Press.

Bakhtin, M. (1986). Speech genres and other late essays. (M. Holquist \& C. Emerson, Eds., V. W. McGee, Trans.). Austin, Texas: University of Texas Press.

Bakhtin, M. M. M. (1990). Art and answerability: Early philosophical essays by MM Bakhtin. Austin: University of Texas Press.

Bakhtin, M. M. (1993). Toward a philosophy of the act. (M. Holquist, Ed., V. Liapunov, Trans.). Austin: University of Texas Press.

Boyd, M. P., \& Markarian, W. C. (2011). Dialogic teaching: Talk in service of a dialogic stance. Language and Education, 25(6), 515-534. https://doi.org/10.1080/09500782.2011.597861

Brandist, C. (2011). Bakhtin and pedagogy. In E. J. White \& M. A. Peters (Eds.), Bakhtinian Pedagogy: Opportunities and Challenges for Research, Policy and Practice in Education Across the Globe. New York: Peter Lang Publishing Inc.

Gemzøe, A. (1998). Bachtin, autor-iteten og modernismen. [Bakhtin, author-ity and modernism]. K\&KKultur Og Klasse, 26(86), 63-84.

Gemzøe, A. (2001). Author and Reader According to Bakhtin: elements of a Modern Prosaics. Aalborg: Aalborg Universitetsforlag.

Hein, P. (1940). Gruk. København: Borgen.

Hodgson, J., Rønning, W., \& Tomlinson, P. (2012). Sammenhengen Mellom Undervisning og Læring. En studie av læreres praksis og deres tenkning under Kunnskapsløftet. Sluttrapport [The connection between teaching and learning. A study of teachers' practice and their thinking] (No. NF-rapport nr. 4/2012). Nordlandsforskning.

Holquist, M. (1990). Dialogism: Bakhtin and his world. London: Routledge. 


\section{Dialogic Discourse Analysis: A methodology for dealing with the classroom as a text}

Atle Skaftun

Igland, M.-A., Skaftun, A., \& Husebø, D. (Eds.). (2019). Ny hverdag? Literacy-praksiser i digitaliserte klasserom på ungdomstrinnet. [Literacy-practices in digitalized secondary classrooms]. Oslo: Universitetsforlaget.

Kachtur, R., and C. Pendergast. 1997. A closer look at authentic interaction: Profiles of teacher-student talk in two classrooms. In. M. Nystrand (ed.). Opening dialogue.New York: Teachers College Press.

Klette, K. (Ed.). (2003). Klasserommets praksisformer etter Reform 97 (Forms of practice following Reform 1997]. Oslo: Pedagogisk forskningsinstitutt.

Kuhn, D. (1991). The Skills of Argument. Cambridge University Press.

Lefstein, A. (2008). Changing Classroom Practice Through the English National Literacy Strategy: A Micro-Interactional Perspective. American Educational Research Journal, 45(3), 701-737. https://doi.org/10.3102/0002831208316256

Lensmire, T. J. (1997). The teacher as Dostoevskian novelist. Research in the Teaching of English, 367392.

Major, L., Warwick, P., Rasmussen, I., Ludvigsen, S., \& Cook, V. (2018). Classroom dialogue and digital technologies: A scoping review. Education and Information Technologies, 23(5), 1995-2028. https://doi.org/10.1007/s10639-018-9701-y

Marjanovic-Shane, A. (2014). A paradigmatic disagreement in "Dialogue on Dialogic Pedagogy" by Eugene Matusov and Kiyotaka Miyazaki. Dialogic Pedagogy: An International Online Journal, 2(0). https://doi.org/10.5195/dpj.2014.122

Matusov, E. (2007). Applying Bakhtin Scholarship on Discourse in Education: A Critical Review Essay. Educational Theory, 57(2), 215-237. https://doi.org/10.1111/j.1741-5446.2007.00253.x

Matusov, E. (2009). Journey into dialogic pedagogy. New York: Nova Science Publishers.

Matusov, E. (2011). Authorial teaching and learning. Bakhtinian Pedagogy: Opportunities and Challenges for Research, Policy and Practice in Education across the Globe, 21-46.

Matusov, E. (2018). Ethic authorial dialogism as a candidate for post-postmodernism. Educational Philosophy and Theory, 50(14), 1478-1479. https://doi.org/10.1080/00131857.2018.1461367

Matusov, E., \& Miyazaki, K. (2014). Dialogue on Dialogic Pedagogy. Dialogic Pedagogy: An International Online Journal, 2(0). https://doi.org/10.5195/dpj.2014.121

Matusov, E., Smith, M., Soslau, E., Marjanovic-Shane, A., \& von Duyke, K. (2016). Dialogic Education for and from Authorial Agency. Dialogic Pedagogy, 4. 10.5195/dpj.2016.172

Matusov, E., Marjanovic-Shane, A., Kullenberg, T., \& Curtis, K. (2019). Dialogic analysis vs. discourse analysis of dialogic pedagogy: Social science research in the era of positivism and post-truth. Dialogic Pedagogy: An International Online Journal, 7(0). https://doi.org/10.5195/dpj.2019.272

Mercer, N. (1995). The guided construction of knowledge: Talk amongst teachers and learners. Clevedon: Multilingual matters.

Mercer, N. (2000). Words and minds: How we use language to think together. London: Routledge.

Mercer, N., Wegerif, R. \& Dawes, L. (1999). From social interaction to individual reasoning: an empirical investigation of a possible socio-cultural model of cognitive development. Learning and Instruction, 9(6), 493-516. 
Miyazaki, K. (2011). Encountering Another Dialogic Pedagogy. Journal of Russian \& East European Psychology, 49(2), 36-43. https://doi.org/10.2753/RP01061-0405490205

Morson, G. S., \& Emerson, C. (1990). Mikhail Bakhtin: creation of a prosaics. Stanford: Stanford University Press.

Mortimer, E., \& Scott, P. (2003). Meaning Making In Secondary Science Classrooms. Maidenhead, Philadelphia: Open University Press.

Murphy, P. K., Wilkinson, I. A., Soter, A. O., Hennessey, M. N., \& Alexander, J. F. (2009). Examining the effects of classroom discussion on students' comprehension of text: A meta-analysis. Journal of Educational Psychology, 101(3).

Nystrand, M. (Ed.). (1997). Opening dialogue: understanding the dynamics of language and learning in the English classroom. New York: Teachers College Press.

Nystrand, M. (2006). Research on the role of classroom discourse as it affects reading comprehension. Research in the Teaching of English, 392-412.

Nystrand, M., \& Gamoran, A. (1991). Student Engagement: When Recitation Becomes Conversation. In H. C. Waxman \& H. J. Walberg (Eds.), Effective teaching: Current research (pp. 257-276). Berkeley: McCutchan. Retrieved from http://eric.ed.gov/?id=ED323581

Nølke, H. (2017). Linguistic Polyphony: The Scandinavian Approach: ScaPoLine. Leiden: Brill.

Pariser, E. (2011). The filter bubble: what the Internet is hiding from you. New York: Penguin Press.

Poole, B. (2001). From phenomenology to dialogue: Max Scheler's phenomenological tradition and Mikhail Bakhtin's development from 'Toward a philosophy of the act'to his study of Dostoevsky. In K. Hirschkop \& D. Shepherd (Eds.), Bakhtin and cultural theory. Manchester: Manchester University Press.

Postholm, M. B., \& Emstad, A. B. (2014). Ledelse og læring i skolen. [Management and learning in school] Oslo: Universitetsforlaget.

Reznitskaya, Alina. (2012). Dialogic Teaching: Rethinking Language Use During Literature Discussions. The Reading Teacher, 65(7), 446-456. https://doi.org/10.1002/TRTR.01066

Reznitskaya, Alina, \& Wilkinson, I. A. (2017). The Most Reasonable Answer: Helping Students Build Better Arguments Together. Cambridge, Massachusetts: Harvard Education Press.

Ricœur, P. (1981). Hermeneutics and the human sciences: Essays on language, action and interpretation. Cambridge: Cambridge University Press.

Schön, D. A. (1983). The reflective practitioner: how professionals think in action. Aldershot: Avebury.

Segal, A., \& Lefstein, A. (2016). Exuberant voiceless participation: An unintended consequence of dialogic sensibilities? L1-Educational Studies in Language and Literature, 16, 1-19.

Skaftun, A. (2003). Knut Hamsuns dialogiske realisme: En studie av Børn av tiden," Nabobyen" og På gjengrodde stier; med særlig fokus på autorposisjon, plot og personer [Dialogic realism: A study of authorial position, plot and characters in Hamsun's prose fiction]. Oslo: Unipub forlag.

Skaftun, A. (2009). Litteraturens nytteverdi [The utility of literature]. Bergen: Fagbokforlaget.

Skaftun, A. (2010). Dialogisk diskursanalyse. Litteraturvitenskapelig metode og skolepraksis [Dialogic discourse analysis. A methodology for literary research and school practice]. Tidskrift För Litteraturvetenskap, 40(3). 


\section{Dialogic Discourse Analysis: A methodology for dealing with the classroom as a text}

Atle Skaftun

Skaftun, A., Igland, M.-A., Husebø, D., Nome, S., \& Nygard, A. O. (2017). Glimpses of dialogue: transitional practices in digitalised classrooms. Learning, Media and Technology, 0(0), 1-14. https://doi.org/10.1080/17439884.2017.1369106

Skaftun, A., \& Wagner, Å. K. H. (2019). Oracy in Year One: A blind spot in Norwegian Language and literacy education? L1 Educational Studies in Language and Literature.

Sullivan, P. (2014). Dialogue on Dialogue on Dialogic Pedagogy. Dialogic Pedagogy: An International Online Journal, 2(0). https://doi.org/10.5195/dpj.2014.123

Van Leeuwen, T. (2008). Discourse and practice: New tools for critical discourse analysis. New York: Oxford University Press.

Vygotsky, L. S. (1986). Thought and language. (A. Kozulin, Ed.). Cambridge, Mass.: MIT Press.

Wegerif, R. (2007). Dialogic Education and Technology: Expanding the Space of Learning. New York: Springer Science \& Business Media.

Wegerif, R. (2013). Dialogic: Education for the Internet Age (1 edition). London \& New York: Routledge.

Wegerif, R. (2016). Applying dialogic theory to illuminate the relationship between literacy education and teaching thinking in the context of the Internet age. L1 Educational Studies in Language and Literature, 16, 1-21.

Wegerif, R. (2017). Dialogic Education. Retrieved January 16, 2019, from https://www.researchgate.net/publication/319008133 Dialogic Education Pre-print draft

Wells, C. G. (1999). Dialogic inquiry: towards a sociocultural practice and theory of education. New York: Cambridge University Press.

Wertsch, J. V. (1991). Voices of the mind: a sociocultural approach to mediated action. Cambridge, Massachussets: Harvard University Press.

Wilkinson, I. A., Reznitskaya, A., Bourdage, K., Oyler, J., Glina, M., Drewry, R., Nelson, K. (2017). Toward a more dialogic pedagogy: changing teachers' beliefs and practices through professional development in language arts classrooms. Language and Education, 31(1), 65-82.

White, E. J. (2016). A Philosophy of Seeing: The Work of the Eye/'I' in Early Years Educational Practice. Journal of Philosophy of Education, 50(3), 474-489. https://doi.org/10.1111/1467-9752.12158

\section{(c) $)$ EY}

New articles in this journal are licensed under a Creative Commons Attribution 4.0 United States License.

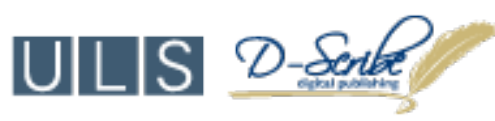


This journal is published by the University Library System, University of Pittsburgh as part of its D-Scribe Digital Publishing Program and is cosponsored by the University of Pittsburgh Press. 